\title{
Current treatment of oral candidiasis: A literature review
}

\author{
Carla Garcia-Cuesta ${ }^{1}$, Maria-Gracia Sarrion-Pérez ${ }^{2}$, Jose V. Bagán ${ }^{3}$
}

\author{
${ }^{1}$ Dentist. Postgraduate in Oral Medicine \\ ${ }^{2}$ Associate profesor of Oral Medicine Unit. Department of Stomatology. University of Valencia \\ ${ }^{3}$ Chairman of Oral Medicine. Oral Medicine Unit. Department of Stomatology. University of Valencia. Head of the Department of \\ Stomatology and Maxilofacial Surgery. Valencia University General Hospital
}

Correspondence:

Avd. / Maestro Rodrigo 13-16

46015 Valencia, Spain

carlagcuesta@gmail.com

Received: 19/06/2014

Accepted: 26/07/2014
Garcia-Cuesta C, Sarrion-Pérez MG, Bagán JV. Current treatment of oral candidiasis: A literature review. J Clin Exp Dent. 2014;6(5):e576-82. http://www.medicinaoral.com/odo/volumenes/v6i5/jcedv6i5p576.pdf

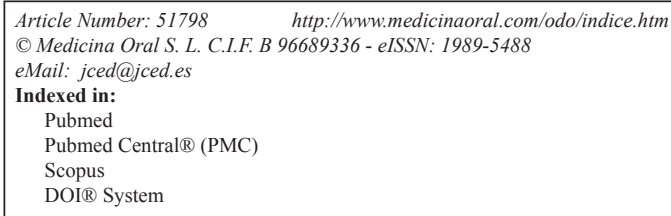

DOIß System

\begin{abstract}
Candidiasis or oral candidosis is one of the most common human opportunistic fungal infections of the oral cavity. This pathology has a wide variety of treatment which has been studied until these days. The present study offers a literature review on the treatment of oral candidiasis, with the purpose of establish which treatment is the most suitable in each case. Searching the 24 latest articles about treatment of candidiasis it concluded that the incidence depends on the type of the candidiasis and the virulence of the infection. Although nystatin and amphotericin b were the most drugs used locally, fluconazole oral suspension is proving to be a very effective drug in the treatment of oral candidiasis. Fluconazole was found to be the drug of choice as a systemic treatment of oral candidiasis. Due to its good antifungal properties, its high acceptance of the patient and its efficacy compared with other antifungal drugs. But this drug is not always effective, so we need to evaluate and distinguish others like itraconazole or ketoconazole, in that cases when Candida strains resist to fluconazole.
\end{abstract}

Key words: Candidiasis, treatment, miconazole, fluconazole, nystatin.

\section{Introduction}

The incidence of fungal infections has been increasing over the last decades, being more prevalent in developed countries (1). An increase incidence of the infections is associated with some predisposing factors (Table 1) as the use of dentures, xerostomia, prolonged therapy with antibiotics, local trauma, malnutrition, endocrine disorders, increased longevity of people, among other states that diminish the quality of defense of the individual (2). Oral candidiasis is one of the most common clinical features of those patients infected with the human immunodeficiency virus [HIV], this manifestation was seen in up to $90 \%$ of individuals infected with HIV (3).
Table 1. Predisposing factors.

\begin{tabular}{|l|c|}
\hline Systemic & Local \\
\hline Hormonal disorders & Epithelial changes \\
\hline Physiological disorders & Poor oral hygiene \\
\hline Endocrine disorders & Loss of vertical dimension \\
\hline Immunologic disorders & Poor fitting dentures \\
\hline Xerostomia & Smoking \\
\hline Drug therapy & \\
\hline Alcohol & \\
\hline
\end{tabular}

Oropharyngeal candidiasis is caused by the genus Candida; it is possible to isolate about 150 species. Many of these remain as a commensal micro-organism in hu- 
mans, which could act as an opportunistic pathogens often associated with predisposing factors attributed to the organism, thereby causing acute or chronic infections (4). The most important of these species is $C$. albicans, which is most commonly isolated from the oral cavity and is believed to be more virulent in humans, occurring in approximately $50 \%$ of the cases of candidiasis.

Clinically there are a number of different types of oral candidiasis (Table 2). Therefore the choice of therapy is guided by the type of candidiasis.

The diagnosis of oral candidiasis is essentially clinical and is based on the recognition of the lesions by the professional, which can be confirmed by the microscopic identification of Candida (5). The techniques available for the isolation of Candida in the oral cavity include direct examination or cytological smear, culture of microorganisms and biopsy which is indicated for cases of hiperplasic candidiasis because this type could present dysplasias (6).

The treatment of oral candidiasis is based on four fundaments (7): making an early and accurate diagnosis of the infection; Correcting the predisposing factors or underlying diseases; Evaluating the type of Candida infec- tion; Appropriate use of antifungal drugs, evaluating the efficacy / toxicity ratio in each case.

When choosing between some treatments it will take into account the type of Candida, its clinical pathology and if it is enough with a topical treatment or requires a more complex systemic type (8), always evaluating the ratio efficacy and toxicity (9). The different drugs are contained in table 3 .

Regular oral and dental hygiene with periodic oral examination will prevent most cases of oral candidiasis, so it is need to make the patient aware of oral hygiene measures. Oral hygiene involves cleaning the teeth, buccal cavity, tongue, and dentures. As well as the use of antiCandida rinses such as Chlorhexidine or Hexetidine, so that they can penetrate those areas where the brush does not. In addition, the need to remove the dentures at night and wash it consciously, leaving it submerged in a disinfectant solution like Chlorhexidine (10).

This study provides a literature review of the treatment of oral candidiasis and its objectives are to establish general guidelines for treatment of oral candidiasis; Assess the drug of choice for local treatment of oral candidiasis; Assess the systemic treatment for oral candidiasis.

Table 2. Clinical classification.

\begin{tabular}{|l|c|c|}
\hline Acute & Chronic & Other lesions \\
\hline Pseudomembranous & Pseudomembranous & Angular cheilitis \\
\hline Erythematous & Erythematous & Denture-associated erythematous \\
\hline & Hyperplastic & Median rhomboid glossitis \\
\hline
\end{tabular}

Table 3. Antifungal agents. Vademecum.

\begin{tabular}{|c|c|c|c|}
\hline DRUG & FORMULATION & DOSE & ADVERSE EFFECT \\
\hline Anfotericin b & $50 \mathrm{mg}$ for infusion & $100-200 \mathrm{mg} / 6 \mathrm{~h}$ & Renal, cardiovascular, spinal and neurological \\
\hline Nystatin & $\begin{array}{l}\text { Suspension } 60 \mathrm{ml} \\
\text { Ointment } 30 \mathrm{~g} \\
\text { Tablets }\end{array}$ & $\begin{array}{c}4-6 \mathrm{ml} / 6 \mathrm{~h} \\
2 \text { to } 4 \text { applications / day } \\
2 \text { every } 8 \mathrm{~h}\end{array}$ & $\begin{array}{l}\text { Well tolerated. } \\
\text { Uncommon } \\
\text { Nausea, vomiting, gastrointestinal effects }\end{array}$ \\
\hline Clotrimazole & $\begin{array}{c}\text { Gel } 1 \% \\
\text { Tablets } 10 \mathrm{mg}\end{array}$ & $\begin{array}{l}3 \text { times / day } \\
5 \text { times / day }\end{array}$ & Occasionally Skin irritation, burning sensation \\
\hline Miconazole & Gel & $100 \mathrm{mg} / 6 \mathrm{~h}$ & $\begin{array}{c}\text { Uncommon } \\
\text { Burning, irritation, nausea, diarrhea, }\end{array}$ \\
\hline Ketoconazole & $\begin{array}{c}\text { Gel } 2 \% \\
\text { Tablets } \\
\text { Suspension } 30 \text { or } 10 \mathrm{cc} \\
\end{array}$ & $\begin{array}{l}3 \text { times/ day } \\
200 \mathrm{mg} \mathrm{1-2/day}\end{array}$ & $\begin{array}{l}\text { Nausea, vomiting } \\
\text { Abdominal pain. }\end{array}$ \\
\hline Fluconazole & $\begin{array}{c}\text { Tablets } \\
\text { Suspension } \\
\end{array}$ & $\begin{array}{c}50-100 \mathrm{mg} / \text { day } \\
10 \mathrm{mg} / \mathrm{ml}\end{array}$ & Nausea, vomiting, diarrhea, abdominal pain. \\
\hline Itraconazole & Capsule & $100-200 \mathrm{mg} /$ day & Nausea, vomiting, diarrhea, abdominal pain. \\
\hline
\end{tabular}




\section{Material and Methods}

A Medline-PubMed search was made using the following key words: " oral candidiasis" OR "oral candidosis" AND amphotericin, "oral candidiasis" OR "oral candidosis" AND nystatine, "oral candidiasis" OR "oral candidosis" AND miconazole, "oral candidiasis" OR "oral candidosis" AND ketoconazole, "oral candidiasis" OR “oral candidosis" AND clotrimazole, "oral candidiasis" OR "oral candidosis" AND fluconazole, "oral candidiasis" OR "oral candidosis" AND itraconazole, "oral candidiasis" OR “oral candidosis" AND treatment, "oral candidiasis" OR "oral candidosis" AND "antifungal therapy". The key words were validated by the MeSH [Medical Subject Headings] dictionary, with use of the boolean operator "AND" to relate them.

The following limits for inclusion of the studies were established: articles published from 2000, publications in English and Spanish and publications of studies in humans. All systematic reviews, clinical trials, meta-analysis and comparative studies were considered in this review.

A total of 109 articles were identified, of which 30 were selected after reading the abstracts. Following analysis of the 30 articles, we finally included a total of 24 , since those publications that did not fit the aims of the present study were excluded.

\section{Results}

A total of 24 articles were found about antifungal treatment, of which 20 were clinical trials, 3 systematic reviews and 1 a clinical case (Table 4).

\section{Discussion}

Candida infection today is highly prevalent, especially the increase in carriers of removable dentures and poor oral hygiene society. Depending on its virulence, location and type of candidiasis there will carry on one treatment or another.

First has been supported the use of conservative measures before starting drug treatment, promoting good oral hygiene along with removing the dentures at night, thereby it will benefit the removal of the biofilm layer generated in the prosthetic surface (11). Dentists should also correct the predisposing factors and underlying diseases and try to promote the use of oral antiseptic and antibacterial rinses such as Chlorhexidine or Hexetidine (12). These measures are very effective in patients with denture stomatitis (12). It was also found in the study of Cross et al. (13) that in patients with good oral hygiene the recurrence of candidiasis after 3 years was lower.

Regarding the pharmacological treatment of candidiasis can be distinguished between two procedures. Topical drugs, which are applied to the affected area and treat superficial infections and systemic drugs those that are prescribed when the infection is more widespread and has not been enough with the topical therapy.
As first choice for local treatment has been for years the nystatin at doses of $100000 \mathrm{IU} / \mathrm{ml}$ [5ml 4 times daily] and amphotericin $\mathrm{b}$ at $50 \mathrm{mg}$ [5ml 3 times per day]. This choice is because they are poorly absorbed by the intestinal tract and therefore most of the antifungal is excreted without undergoing any change, thereby reducing hepatotoxicity (14). However, the unpleasant taste and prolonged pattern compromise treatment compliance by the patient (14-16).

Throughout the years it has been studying the effectiveness of other drugs like fluconazole oral solution. Many authors have focused on evaluating the efficacy and safety of fluconazole oral solution for the treatment of oropharyngeal candidiasis, especially pseudomembranous type, giving good results, although many studies are still needed (14-18).

In a recent study conducted in 19 patients with pseudomembranous candidiasis show that fluconazole suspension in distilled water $[2 \mathrm{mg} / \mathrm{ml}]$ reaches a $95 \%$ cure.

The guideline was to rinse with $5 \mathrm{ml}$ of the drug solution for 1 minute and then spit it out and repeat this action 3 times a day for 1 week. Another study which included 36 children with pseudomembranous candidiasis showed that fluconazole oral suspension $10 \mathrm{mg} / \mathrm{ml}$ dose gave better results than nystatin. The main problem was the poor adherence of the nystatin to the oral mucosa and thus the quick ingestion of the suspension, resulting in a lower efficiency (14).

On the other hand, in another study comparing amphotericin b suspension, the fluconazole oral suspension gave better results in terms of the eradication of Candida (16). The same was corroborated by Taillandier et al. (18), which reported that fluconazole oral suspension was as effective as amphotericin b, but it was better accepted by the patient.

Fluconazole oral suspension is administered in a dosage of $10 \mathrm{mg} / \mathrm{ml}$ aqueous suspension by administering $5 \mathrm{ml}$ daily for 7 or 14 days. Different studies show that it is a very effective drug against pseudomembranous candidiasis, as it has good adhesion to the surface of the oral mucosa and a rapid symptomatic response. It also offers the convenience of a one-daily dosing, which may explain the better patient compliance (14-18).

Another topic drug widely used is miconazole (19). We found it in the form of gel, applying it directly on the affected area, at doses of 200-500 mg per day, divided into 4 times. Despite its good properties it has the drawback of possible interaction with other drugs, such as warfarin. This is because the antifungal inhibit the enzyme cytochrome P-450, which affects the clearance of certain drugs $(20,21)$. In addition, this drug is absorbed by the intestine, therefore care must be taken when is administrated.

It has been introduced in the market an alternative presentation of miconazole. A one-daily miconazole $50 \mathrm{mg}$ 
'Table 4. Summarized articles.

\begin{tabular}{|c|c|c|c|c|c|}
\hline Author/ Year & Article & $\begin{array}{l}\text { Type of article } \\
\text { / Sample }\end{array}$ & Drug & Dose & Conclusions \\
\hline $\begin{array}{l}\text { Manfredi et } \\
\text { al. (11) } 2006\end{array}$ & $\begin{array}{l}\text { In vitro antifungal susceptibility to } \\
\text { six antifungal agents of } 229 \\
\text { Candida isolates from patients } \\
\text { with diabetes mellitus }\end{array}$ & $\begin{array}{l}\text { Clinical trial } \\
\mathrm{n}=821\end{array}$ & $\begin{array}{l}\text { Itraconazole } \\
\text { Miconazole } \\
\text { Ketoconazole } \\
\text { Fluconazole } \\
\text { Anfotericin b } \\
\end{array}$ & $\begin{array}{l}\text { In vitro } \\
\text { preparations }\end{array}$ & $\begin{array}{l}\text { Those strains that were } \\
\text { resistant to fluconazole } \\
\text { also were resistant to } \\
\text { other drugs. }\end{array}$ \\
\hline $\begin{array}{l}\text { Koray et al. } \\
\text { (12) } \\
2005\end{array}$ & $\begin{array}{l}\text { Fluconazole and/or hexetidine for } \\
\text { management of oral candidiasis } \\
\text { associated with denture-induced } \\
\text { stomatitis }\end{array}$ & $\begin{array}{l}\text { Clinical trial } \\
\qquad \mathrm{n}=61\end{array}$ & $\begin{array}{c}\text { Hexetidine rinse } \\
\text { Heksoral }{ }^{\circledR} \\
0,1 \% \\
\text { Fluconazole } \\
\text { Zolax® cap- } \\
\text { sules } \\
\end{array}$ & $50 \mathrm{mg} \mathrm{1/d}$ & $\begin{array}{l}\text { Supports the use of } \\
\text { antiseptics or } \\
\text { hexetidine as a first } \\
\text { choice. } \\
\text { Conservative i } \\
\text { ntervention }\end{array}$ \\
\hline $\begin{array}{l}\text { Cross et al. } \\
(13) \\
2004\end{array}$ & $\begin{array}{l}\text { Evaluation of the recurrence of } \\
\text { denture stomatitis and Candida } \\
\text { colonization in a small group of } \\
\text { patients who received itraconazole }\end{array}$ & $\begin{array}{l}\text { Clinical trial } \\
n=22\end{array}$ & $\begin{array}{l}\text { Itraconazole } \\
\text { rinse } \\
\text { Itraconazole } \\
\text { capsules }\end{array}$ & 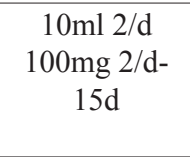 & $\begin{array}{l}\text { Best systemic } \\
\text { itraconazole }\end{array}$ \\
\hline $\begin{array}{l}\text { Goins et al. } \\
\text { (14) } \\
2002\end{array}$ & $\begin{array}{l}\text { Comparison of fluconazole and ny- } \\
\text { statin oral suspension for treatment } \\
\text { of oral candidiasis in infants }\end{array}$ & $\begin{array}{l}\text { Clinical trial } \\
\qquad \begin{array}{c}n=19 \\
n=15\end{array}\end{array}$ & $\begin{array}{l}\text { Nystatin sus- } \\
\text { pension } \\
\text { Fluconazole } \\
\text { suspension } \\
\text { (Diflucan } \AA)\end{array}$ & $\begin{array}{c}1 \mathrm{ml} \\
4 / \mathrm{d}-10 \mathrm{~d} \\
10 \mathrm{mg} / \mathrm{ml} \\
1 / \mathrm{d}-7 \mathrm{~d}\end{array}$ & $\begin{array}{l}\text { Fluconazole more } \\
\text { effective }\end{array}$ \\
\hline $\begin{array}{l}\text { Epstein et al. } \\
(15) \\
2002\end{array}$ & $\begin{array}{l}\text { Fluconazole mouthrinses for oral } \\
\text { candidiasis in postirradiation } \\
\text { transplant, and other patients }\end{array}$ & $\begin{array}{l}\text { Clinical trial } \\
n=19\end{array}$ & $\begin{array}{l}\text { Fluconazole } \\
\text { oral solution }\end{array}$ & $5 \mathrm{ml} \mathrm{3/d}$ & Clinical improvements \\
\hline $\begin{array}{l}\text { Lefebvre et } \\
\text { al. }(16) \\
2002\end{array}$ & $\begin{array}{l}\text { A comparative study of the } \\
\text { efficacy and safety of fluconazole } \\
\text { oral suspension and } \\
\text { amphotericin B oral suspension in } \\
\text { cancer patients with mucositis }\end{array}$ & $\begin{array}{c}\text { Clinical trial } \\
\mathrm{n}=123 \\
\mathrm{n}=1201\end{array}$ & $\begin{array}{l}\text { Fluconazole } \\
\text { oral solution } \\
5 \mathrm{ml}\end{array}$ & $\begin{array}{c}5 \mathrm{ml}(50 \mathrm{mg}) \\
1 / \mathrm{d} \\
\\
5 \mathrm{ml}-3 / \mathrm{d} \\
7-14 \mathrm{~d}\end{array}$ & $\begin{array}{l}\text { Better accepted the } \\
\text { fluconazole }\end{array}$ \\
\hline $\begin{array}{l}\text { Sholapurkar } \\
\text { et al. (17) } \\
2009\end{array}$ & $\begin{array}{l}\text { Comparison of efficacy of } \\
\text { fluconazol mouthrinse and } \\
\text { clotrimazole mouthpaint in the } \\
\text { treatment of oral candidiasis }\end{array}$ & $\begin{array}{c}\text { Clinical trial } \\
\mathrm{n}=27 \\
\mathrm{n}=28\end{array}$ & $\begin{array}{l}\text { Fluconazole } \\
\text { Clotrimazole }\end{array}$ & $\begin{array}{c}5 \mathrm{ml} \\
3 / \mathrm{d}-14 \mathrm{~d} \\
\begin{array}{c}\text { mouthpaint } \\
\text { 3/d }\end{array} \\
\end{array}$ & $\begin{array}{l}\text { Mayor cure rate with } \\
\text { fluconazole }\end{array}$ \\
\hline $\begin{array}{l}\text { Taillander et } \\
\text { al. }(18) \\
2000\end{array}$ & $\begin{array}{l}\text { A comparison of fluconazole oral } \\
\text { suspension and amprotericin B oral } \\
\text { suspension in older patients with } \\
\text { oropharyngeal candidosis }\end{array}$ & $\begin{array}{l}\text { Clinical trial } \\
\mathrm{n}=150 \\
\mathrm{n}=155\end{array}$ & $\begin{array}{c}\text { Fluconazole } \\
\text { oral suspension } \\
\text { Anfotericin b } \\
\text { oral suspension }\end{array}$ & $\begin{array}{l}5 \mathrm{ml}(50 \mathrm{mg}) \\
1 / \mathrm{d} \\
5 \mathrm{ml}-3 / \mathrm{d}\end{array}$ & $\begin{array}{l}\text { No significant } \\
\text { difference }\end{array}$ \\
\hline $\begin{array}{l}\text { Isham et al. } \\
\text { (19) } 2010\end{array}$ & $\begin{array}{l}\text { Antifungal activity of miconazole } \\
\text { against recent Candida strains }\end{array}$ & $\begin{array}{c}\text { Clinical trial } \\
\mathrm{n}=25\end{array}$ & Miconazole & $\begin{array}{l}\text { In vitro pre- } \\
\text { paration }\end{array}$ & $\begin{array}{l}\text { Miconazole presents } \\
\text { great inhibitory activity }\end{array}$ \\
\hline $\begin{array}{l}\text { Pemberton et } \\
\text { al. }(20) \\
2004\end{array}$ & $\begin{array}{l}\text { Miconazole oral gel and drug } \\
\text { interactions }\end{array}$ & Clinical case & Miconazole gel & $125 \mathrm{mg} / \mathrm{d} 3 \mathrm{~d}$ & $\begin{array}{l}\text { Decreased the } \\
\text { clearance of some } \\
\text { drugs and is absorbed } \\
\text { by the intestine }\end{array}$ \\
\hline $\begin{array}{l}\text { Miki et al. } \\
(21) \\
2011\end{array}$ & $\begin{array}{l}\text { Warfarin and miconazole oral gel } \\
\text { interactions: analysis and therapy } \\
\text { recommendations based on clinical } \\
\text { data and a pharmacokinetic model }\end{array}$ & $\begin{array}{l}\text { Systematic } \\
\text { review }\end{array}$ & Miconazole gel & $200-400 \mathrm{mg} / \mathrm{d}$ & $\begin{array}{l}\text { Interactions with other } \\
\text { drugs }\end{array}$ \\
\hline $\begin{array}{l}\text { Collins et al. } \\
(22) \\
2011\end{array}$ & $\begin{array}{l}\text { Management of oropharyngeal } \\
\text { candidiasis with localized oral } \\
\text { miconazole therapy: efficacy, } \\
\text { safety, and patient acceptability }\end{array}$ & $\begin{array}{l}\text { Systematic } \\
\text { review }\end{array}$ & $\begin{array}{l}\text { Miconazole } \\
\text { buccal tablets }\end{array}$ & $50 \mathrm{mg} 1 / \mathrm{d}$ & $\begin{array}{l}\text { Limited systemic } \\
\text { absorption. Good } \\
\text { efficacy }\end{array}$ \\
\hline $\begin{array}{l}\text { Vazquez et al. } \\
\text { (23) } \\
2012\end{array}$ & $\begin{array}{l}\text { Miconazole Mucoadhesive Tablets: } \\
\text { A Novel Delivery System }\end{array}$ & $\begin{array}{l}\text { Systematic } \\
\text { review } \\
\mathrm{n}=25\end{array}$ & $\begin{array}{l}\text { Miconazole } \\
\text { mucoadhesive } \\
\text { tablets }\end{array}$ & $50 \mathrm{mg} 1 / \mathrm{d}$ & $\begin{array}{l}\text { Little systemic } \\
\text { absorption. } \\
94.7 \% \text { efficacy }\end{array}$ \\
\hline
\end{tabular}




\begin{tabular}{|c|c|c|c|c|c|}
\hline Author/ Year & Article & \begin{tabular}{|c|}
$\begin{array}{c}\text { Type of article } \\
\text { / Sample }\end{array}$ \\
\end{tabular} & Drug & Dose & Conclusions \\
\hline $\begin{array}{l}\text { Czerninski et } \\
\text { al. }(24) \\
2010\end{array}$ & $\begin{array}{c}\text { A novel sustained-release } \\
\text { clotrimazole varnish for local treatment of } \\
\text { oral candidiasis }\end{array}$ & $\begin{array}{c}\text { Clinical trial } \\
\mathrm{n}=14 \\
\end{array}$ & $\begin{array}{l}\text { Clotrimazole } \\
\text { varnish and } \\
\text { troches }\end{array}$ & 5 times $/ \mathrm{d}$ & $\begin{array}{c}\text { Varnish more } \\
\text { prolonged effect }\end{array}$ \\
\hline $\begin{array}{l}\text { Oji et al. (25) } \\
2008\end{array}$ & $\begin{array}{c}\text { Evaluation and treatment of oral } \\
\text { candidiasis in HIV/AIDS patient in } \\
\text { Enugu, Nigeria }\end{array}$ & $\begin{array}{l}\text { Clinical trial } \\
\qquad n=29\end{array}$ & $\begin{array}{l}\text { Nystatin rinses } \\
\text { (micostatin } ®) \\
\text { Ketoconazole } \\
\text { tablets } \\
\text { (nizoral } \AA)\end{array}$ & $\begin{array}{c}5 \mathrm{ml} \\
4 / \mathrm{d}-14 \mathrm{~d} \\
200 \mathrm{mg} / \mathrm{d} \\
14 \mathrm{~d}\end{array}$ & $\begin{array}{l}\text { For HIV patients, } \\
\text { more effective the } \\
\text { systemic treatment } \\
\text { (ketoconazole) }\end{array}$ \\
\hline $\begin{array}{l}\text { Bensadoun et } \\
\text { al. }(26) \\
2008\end{array}$ & $\begin{array}{l}\text { Comparison of the efficacy and safety of } \\
\text { miconazole 50-mg mucoadhesive buccal } \\
\text { tablets with miconazole } 500 \text {-mg gel in the } \\
\text { treatment of oropharyngeal } \\
\text { candidiasis }\end{array}$ & $\begin{array}{l}\text { Clinical trial } \\
n=141\end{array}$ & $\begin{array}{l}\text { Miconazole } \\
\text { mucoadhesive } \\
\text { tablets } \\
\text { Miconazole gel }\end{array}$ & $\begin{array}{l}50 \mathrm{mg} 1 / \mathrm{d} \\
125 \mathrm{mg} 4 / \mathrm{d}\end{array}$ & $\begin{array}{l}\text { Best treatment plan } \\
\text { the mucoadhesive } \\
\text { tablets }\end{array}$ \\
\hline $\begin{array}{l}\text { Koks et al. } \\
(27) \\
2002\end{array}$ & $\begin{array}{l}\text { Prognostic factors for the clinical } \\
\text { effectiveness of fluconazole in the } \\
\text { treatment of oral candidiasis in HIV-1- } \\
\text { infected individuals }\end{array}$ & $\begin{array}{l}\text { Clinical trial } \\
n=28\end{array}$ & $\begin{array}{l}\text { Fluconazole } \\
\text { capsules } \\
\text { Diflucan }{ }^{\circledR}\end{array}$ & $100 \mathrm{mg} / \mathrm{d}$ & $\begin{array}{l}\text { Great efficacy of } \\
\text { fluconazole }\end{array}$ \\
\hline $\begin{array}{l}\text { Lyon et al. } \\
(28) \\
2006\end{array}$ & $\begin{array}{l}\text { Correlation between adhesion, } \\
\text { enzyme production, and } \\
\text { susceptibility to fluconazole in Candida } \\
\text { albicans obtained from dentures wearers }\end{array}$ & $\begin{array}{l}\text { Clinical trial } \\
\qquad n=99\end{array}$ & Fluconazole & $\begin{array}{l}\text { In vitro } \\
\text { preparations }\end{array}$ & $\begin{array}{l}\text { Fluconazole } \\
\text { reduces erythema } \\
\text { and cell } \\
\text { colonization }\end{array}$ \\
\hline $\begin{array}{l}\text { Oude Lashof } \\
\text { et al. }(29) \\
2004\end{array}$ & $\begin{array}{l}\text { An open multicentre } \\
\text { comparative study of the efficacy, safety } \\
\text { and tolerance of fluconazole and } \\
\text { itraconazole in the treatment of cancer } \\
\text { patients with oropharyngeal candidiasis }\end{array}$ & $\begin{array}{l}\text { Clinical trial } \\
n=252\end{array}$ & $\begin{array}{l}\text { Fluconazole } \\
\text { capsules } \\
\text { Itraconazole } \\
\text { capsules }\end{array}$ & $\begin{array}{l}100 \mathrm{mg} 1 / \mathrm{d}- \\
10 \mathrm{~d} \\
200 \mathrm{mg} 1 / \mathrm{d}- \\
15 \mathrm{~d}\end{array}$ & $\begin{array}{l}\text { Fluconazole better } \\
\text { result }\end{array}$ \\
\hline $\begin{array}{l}\text { Kuriyama et } \\
\text { al. }(30) \\
2005\end{array}$ & $\begin{array}{c}\text { In vitro susceptibility of oral } \\
\text { Candida to seven antifungal agents }\end{array}$ & $\begin{array}{l}\text { Clinical trial } \\
\qquad \mathrm{n}=521\end{array}$ & $\begin{array}{l}\text { Fluconazole } \\
\text { Itraconazole } \\
\text { Voriconazole } \\
\text { Ketoconazole } \\
\text { Miconazole } \\
\text { Anfotericin b } \\
\text { Nystatin } \\
\end{array}$ & $\begin{array}{l}\text { In vitro } \\
\text { preparations }\end{array}$ & $\begin{array}{l}\text { Some Candida } \\
\text { species are resistant } \\
\text { to antifungal drugs }\end{array}$ \\
\hline $\begin{array}{l}\text { Brito et al. } \\
\text { (31) } \\
2011\end{array}$ & $\begin{array}{l}\text { In vitro antifungal susceptibility of } \\
\text { Candida spp. Oral isolates from HIV- } \\
\text { positive patients and control individuals }\end{array}$ & $\begin{array}{l}\text { Clinical trial } \\
\mathrm{n}=71 \text { cepas de } \\
\text { Cándida }\end{array}$ & $\begin{array}{l}\text { Anfotericin b } \\
\text { Fluconazole } \\
\text { Flucytosine } \\
\text { Nystatin } \\
\text { Ketoconazole }\end{array}$ & $\begin{array}{l}\text { In vitro pre- } \\
\text { parations }\end{array}$ & $\begin{array}{l}\text { Antifungal agents } \\
\text { showed good } \\
\text { activity against the } \\
\text { strains }\end{array}$ \\
\hline $\begin{array}{l}\text { Ally et al. } \\
(32) \\
2001\end{array}$ & $\begin{array}{l}\text { A randomized, double-blind, } \\
\text { double-dummy, multicenter trial of } \\
\text { voriconazole and fluconazole in the } \\
\text { treatment of esophageal candidiasis in } \\
\text { immunocompromised patients }\end{array}$ & $\begin{array}{l}\text { Comparative } \\
\text { clinical trial } \\
n=256\end{array}$ & $\begin{array}{l}\text { Fluconazole } \\
\text { capsules } \\
\text { Voriconazole } \\
\text { capsules }\end{array}$ & $\begin{array}{l}200 \mathrm{mg} 1 / \mathrm{d} \\
200 \mathrm{mg} 1 / \mathrm{d}\end{array}$ & $\begin{array}{l}\text { Voriconazole was at } \\
\text { least as effective as } \\
\quad \text { fluconazole }\end{array}$ \\
\hline $\begin{array}{l}\text { Khozeimeh et } \\
\text { al. (33) } \\
2010\end{array}$ & $\begin{array}{c}\text { Comparative evaluation of } \\
\text { ketoconazole tablet and topical } \\
\text { ketoconazole } 2 \% \text { in orabase in treatment } \\
\text { of Candida-infected denture stomatitis. }\end{array}$ & $\begin{array}{l}\text { Clinical trial } \\
\qquad \mathrm{n}=30\end{array}$ & $\begin{array}{l}\text { Ketoconazole } \\
\text { systemic } \\
\text { Ketoconazole } \\
\text { topical } \\
\text { Miconazole } \\
\text { mucoadhesive } \\
\text { tablet } \\
\end{array}$ & $\begin{array}{l}200 \mathrm{mg} 1 / \mathrm{d} \\
2 \% 2 / \mathrm{d} \\
50 \mathrm{mg}\end{array}$ & $\begin{array}{c}\text { Miconazole } \\
\text { mucoadhesive } \\
\text { tablet used as } \\
\text { first-line treatment } \\
\text { because of its good } \\
\text { tolerance }\end{array}$ \\
\hline $\begin{array}{l}\text { Van Roey et } \\
\text { al. }(34) \\
2004\end{array}$ & $\begin{array}{l}\text { Comparative efficacy of topical therapy } \\
\text { with a slow-release mucoadhesive buccal } \\
\text { tablet containing miconazole nitrate } \\
\text { versus systemic therapy with } \\
\text { ketoconazole in HIV-positive patients } \\
\text { with oropharyngeal candidiasis }\end{array}$ & $\begin{array}{l}\text { Clinical trial } \\
\qquad \begin{array}{l}n=167 \\
n=165\end{array}\end{array}$ & $\begin{array}{l}\text { Miconazole } \\
\text { mucoadhesive } \\
\text { tablet } \\
\text { Ketoconazole } \\
\text { tablets }\end{array}$ & $\begin{array}{l}400 \mathrm{mg} \\
1 / \mathrm{d}-14 \mathrm{~d}\end{array}$ & $\begin{array}{l}\text { Miconazole } \\
\text { mucoadhesive } \\
\text { tablets were as } \\
\text { effective as other } \\
\text { systemic drugs }\end{array}$ \\
\hline
\end{tabular}


mucoadhesive buccal tablet. It has a limited systemic absorption. Its performance is mostly local and it has a convenient application form. Patients are instructed to apply the rounded side of the $50 \mathrm{mg}$ tablet to the upper gum region just above the right or left incisor following brushing of teeth in the morning. The tablet should be held in place until dissolved $(22,23)$. It has the advantage of being applied once daily instead 5 times a day with clotrimazole (24), and 4 times daily with nystatin (25). It has been demonstrated the effectiveness of this new form of administration in the study of Bensadoun et al. (26). 141 patients with head and neck cancer with clinical signs and symptoms of oropharyngeal candidiasis received $50 \mathrm{mg}$ mucoadhesive tablets of miconazole daily or $125 \mathrm{mg}$ miconazole gel four times per day. Clinical improvement was not significant between the two groups, but the mucoadhesive tablets exhibited higher salivary concentrations and better tolerance for the patient. Despite being more expensive, offers an effective, safe, and well tolerated topical treatment for oropharyngeal candidiasis $(22,23,26)$.

- Systemic treatment:

In spite of knowing the efficacy of the drugs listed above, when it comes to a more generalized candidiasis or immunocompromised patients, these would not be sufficient. For those cases would have to resort to treatment with systemic drugs (25).

Since its introduction, fluconazole has been used to treat systemic Candida infections because of its efficacy and good tolerability. The appropriate dose is between 50 $100 \mathrm{mg}$ daily (27). Furthermore, when dealing with immunocompromised patients, such as those HIV-infected, or cancerous, this drug has good effects doubling the dose $(28,29)$. Its efficacy has been demonstrated $(27)$. The dose was individualized depending on the severity and type of candidiasis. Patients with pseudomembranous type started with $100 \mathrm{mg}$ fluconazole daily; patients with erythematous variety started with $50 \mathrm{mg}$ fluconazole. Therefore, according to the clinic and the virulence of the infection the dose would be titrated, giving good results, and increasing the guideline in those cases where the fungal infection did not decrease (27).

To support the efficacy of this drug it has been compared with other systemic antifungal agents (29). In one randomized study, the efficacy of fluconazole $[100 \mathrm{mg}$ per day for 10 days] and itraconazole [200mg per day for 15 days] was compared in patients with oropharyngeal candidiasis. The results were a clinical and mycological improvement of $66 \%$ for the first group and 54\% for those treated with itraconazole. The main conclusion of this study is that in patients with oropharyngeal candidiasis, fluconazole has a significantly better clinical and mycological cure rate compared with itraconazole. The failures of itraconazole may be explained by drug interactions and the unpredictable absorption of itracona- zole capsules. But when fluconazole failed, itraconazole was prescribed to these patients, having good results. So it is said that it was a good drug for fluconazole-resistant Candida strains (29).

As it has been suggested above, it may happen that the Candida strains were not susceptible to fluconazole, and it has not any effect. In that case it will be used other drugs like itraconazole or newest ones as voriconazole (30). Keeping always in mind that strains which were resistant to fluconazole were also resistant to other drugs (31).

The new triazol antifungal voriconazole $[200 \mathrm{mg}$ per day] has been shown to be a potent drug. Ally et al. (32) compared the efficacy of voriconazole and fluconazole in the treatment of esophageal candidiasis. The success rate was $98.3 \%$ for voriconazole and $95.1 \%$ for fluconazole. The results show clearly that voriconazole is at least as effective as fluconazole in the treatment of candidiasis. It suggests that this new agent may be a useful alternative for fluconazole-resistant Candida strains (32). Because of being a new there are little strains resistant to voriconazole. The voriconazole has an important role in the treatment of candidiasis (30), although it is still not fully established in the market, so many more studies and research would be needed.

There have been several studies comparing topical and systemic drugs. In a study to treat denture stomatitis have been compared the use of ketoconazole tablets [200mg daily] with topical ketoconazole [ $2 \%$ twice daily] and miconazole mucoadhesive tablets (33). Due to the adverse effects of ketoconazole (31) like nausea, vomiting and gastrointestinal problems it has been supported the use of other drugs when treating prosthetic candidiasis (34). Thus the use of miconazole mucoadhesive tablet was established as the drug of first line of defense for this type of candidiasis.

General treatment guidelines include after the completion of an early diagnosis, the correction of predisposing factors or underlying diseases and maintaining a good oral hygiene. Moreover using antiseptic agents such as Chlorhexidine or Hexetidine, as well as removing dentures at night. All of that in order to obtain well results in the treatment of oral candidiasis as first line of defense, continuing the application of antifungal drugs. Beginning with local treatment and keeping up the systemic ones for those patients who do not respond to topical treatment or in immunocompromised patients.

It has recently been found that fluconazole oral suspension as a local treatment, at a dose of $2 \mathrm{mg} / \mathrm{ml} 3$ times daily or $10 \mathrm{mg} / \mathrm{ml}$ once daily, gives good clinical results, besides the better patient compliance due to the dosage and its pleasant taste. Despite not being currently the most widely used locally because it requires further clinical studies. Nowadays the most used drugs remains in nystatin solution which contain $100000 \mathrm{IU} / \mathrm{ml}[5 \mathrm{ml} 4$ times daily] and miconazole gel [200 to $500 \mathrm{mg}$ per day 
divided into 4 doses]. Moreover miconazole mucoadhesive tablets [50 mg once daily] which are considered effective in the treatment of oropharyngeal candidiasis, but their high cost is one of the main problems.

Fluconazole at doses between $50-100 \mathrm{mg}$ per day is the systemic drug of choice because it has high efficacy and tolerability by the patient. However it is important to think about the voriconazole which is as effective as fluconazole but is still under study. Also it is need to know about other drugs such as itraconazole, which are effective when Candida strains are resistant to fluconazole.

\section{References}

1. Arendrup MC, Fuursted K, Gahrn-Hansen B, Jensen IM, Knudsen JD, Lundgren B, et al. Seminational surveillance of fungemia in Denmark: notably high rates of fungemia and numbers of isolates with reduced azole susceptibility. J Clin Microbiol. 2005;43:4434-40

2. Rodloff C, Koch D, Schaumann R. Epidemiology and antifungal resistance in invasive candidiasis. Eur J Med Res. 2011;16:187-95.

3. Thompson GR 3rd, Patel PK, Kirkpatrick WR, Westbrook SD, Berg $\mathrm{D}$, Erlandsen J, et al. Oropharyngeal candidiasis in the era of antiretroviral therapy. Oral Surg Oral Med Oral Pathol Oral Radiol Endod. 2010;109:488-95

4. Williams DW, Kuriyama T, Silva S, Malic S, Lewis MA. Candida biofilms and oral candidosis: treatment and prevention. Periodontol 2000. 2011;55:250-65.

5. Coronado-Castellote L, Jiménez-Soriano Y. Clinical and microbiological diagnosis of oral candidiasis. J Clin Exp Dent. 2013;5:e279-86. 6. Byadarahally Raju S, Rajappa S. Isolation and identification of Candida from the oral cavity. ISRN Dent. 2011;2011:487921.

7. Aguirre Urizar JM. Oral Candidiasis. Rev Iberoam Micol. 2002;19:1721.

8. Williams D, Lewis M. Pathogenesis and treatment of oral candidosis. J Oral Microbiol. 2011;28:3.

9. Martínez-Beneyto Y, López-Jornet P, Velandrino-Nicolás A, JornetGarcía V. Use of antifungal agents for oral candidiasis: results of a national survey. Int J Dent Hyg. 2010;8:47-52.

10. Akpan A, Morgan R. Oral candidiasis. Postgrad Med J. 2002;78:455-9.

11. Manfredi M, Polonelli L, Aguirre-Urizar JM, Carrozzo M, McCullough MJ. Urban legends series: oral candidosis. Oral Dis. 2013;19:245-61.

12. Koray M, Ak G, Kurklu E, Issever H, Tanyeri H, Kulekci G, et al. Fluconazole and/or hexetidine for management of oral candidiasis associated with denture-induced stomatitis. Oral Dis. 2005;11:309-13.

13. Cross LJ, Williams DW, Sweeney CP, Jackson MS, Lewis MA, Bagg J. Evaluation of the recurrence of denture stomatitis and Candida colonization in a small group of patients who received itraconazole. Oral Surg Oral Med Oral Pathol Oral Radiol Endod. 2004;97:351-8.

14. Goins RA, Ascher D, Waecker N, Arnold J, Moorefield E. Comparison of fluconazole and nystatin oral suspensions for treatment of oral candidiasis in infants. Pediatr Infect Dis J. 2002;21:1165-7.

15. Epstein JB, Gorsky M, Caldwell J. Fluconazole mouthrinses for oral candidiasis in postirradiation, transplant, and other patients. Oral Surg Oral Med Oral Pathol Oral Radiol Endod. 2002;93:671-5.

16. Lefebvre JL, Domenge C; Study Group of Mucositis. A comparative study of the efficacy and safety of fluconazole oral suspension and amphotericin B oral suspension in cancer patients with mucositis. Oral Oncol. 2002;38:337-42.

17. Sholapurkar AA, Pai KM, Rao S. Comparison of efficacy of fluconazole mouthrinse and clotrimazole mouthpaint in the treatment of oral candidiasis. Aust Dent J. 2009;54:341-6.

18. Taillandier J, Esnault Y, Alemanni M. A comparison of fluconazole oral suspension and amphotericin B oral suspension in older patients with oropharyngeal candidosis. Multicentre Study Group. Age Ageing. 2000;29:117-23.
19. Isham N, Ghannoum MA. Antifungal activity of miconazole against recent Candida strains. Mycoses. 2010;53:434-7.

20. Pemberton MN, Oliver RJ, Theaker ED. Miconazole oral gel and drug interactions. Br Dent J. 2004;196:529-31.

21. Miki A, Ohtani H, Sawada Y. Warfarin and miconazole oral gel interactions: analysis and therapy recommendations based on clinical data and a pharmacokinetic model. J Clin Pharm Ther. 2011;36:64250 .

22. Collins CD, Cookinham S, Smith J. Management of oropharyngeal candidiasis with localized oral miconazole therapy: efficacy, safety, and patient acceptability. Patient Prefer Adherence. 2011;5:369-74.

23. Vazquez JA, Sobel JD. Miconazole mucoadhesive tablets: a novel delivery system. Clin Infect Dis. 2012;54:1480-4.

24. Czerninski R, Sivan S, Steinberg D, Gati I, Kagan L, Friedman M. A novel sustained-release clotrimazole varnish for local treatment of oral candidiasis. Clin Oral Investig. 2010;14:71-8.

25. Oji C, Chukwuneke F. Evaluation and treatment of oral candidiasis in HIV/AIDS patients in Enugu, Nigeria. Oral Maxillofac Surg. 2008; $12: 67-71$

26. Bensadoun RJ, Daoud J, El Gueddari B, Bastit L, Gourmet R, Rosikon A, et al. Comparison of the efficacy and safety of miconazole 50mg mucoadhesive buccal tablets with miconazole 500-mg gel in the treatment of oropharyngeal candidiasis: a prospective, randomized, single-blind, multicenter, comparative, phase III trial in patients treated with radiotherapy for head and neck cancer. Cancer. 2008;112:20411.

27. Koks CH, Crommentuyn KM, Mathôt RA, Mulder JW, Meenhorst PL, Beijnen JH. Prognostic factors for the clinical effectiveness of fluconazole in the treatment of oral candidiasis in HIV-1-infected individuals. Pharmacol Res. 2002;46:89-94.

28. Lyon JP, de Resende MA. Correlation between adhesion, enzyme production, and susceptibility to fluconazole in Candida albicans obtained from denture wearers. Oral Surg Oral Med Oral Pathol Oral Radiol Endod. 2006;102:632-8.

29. Oude Lashof AM, De Bock R, Herbrecht R, de Pauw BE, Krcmery V, Aoun M, et al.; EORTC Invasive Fungal Infections Group. An open multicentre comparative study of the efficacy, safety and tolerance of fluconazole and itraconazole in the treatment of cancer patients with oropharyngeal candidiasis. Eur J Cancer. 2004;40:1314-9.

30. Kuriyama T, Williams DW, Bagg J, Coulter WA, Ready D, Lewis MA. In vitro susceptibility of oral Candida to seven antifungal agents. Oral Microbiol Immunol. 2005;20:349-53.

31. Brito GN, Inocêncio AC, Querido SM, Jorge AO, Koga-Ito CY. In vitro antifungal susceptibility of Candida spp. oral isolates from HIVpositive patients and control individuals. Braz Oral Res. 2011;25:2833.

32. Ally R, Schürmann D, Kreisel W, Carosi G, Aguirrebengoa K, Dupont B, et al. Esophageal Candidiasis Study Group. A randomized, double-blind, double-dummy, multicenter trial of voriconazole and fluconazole in the treatment of esophageal candidiasis in immunocompromised patients. Clin Infect Dis. 2001;33:1447-54.

33. Khozeimeh F, Shahtalebi MA, Noori M, Savabi O. Comparative evaluation of ketoconazole tablet and topical ketoconazole $2 \%$ in orabase in treatment of Candida-infected denture stomatitis. J Contemp Dent Pract. 2010;11:017-24

34. Van Roey J, Haxaire M, Kamya M, Lwanga I, Katabira E. Comparative efficacy of topical therapy with a slow-release mucoadhesive buccal tablet containing miconazole nitrate versus systemic therapy with ketoconazole in HIV-positive patients with oropharyngeal candidiasis. J Acquir Immune Defic Syndr. 2004;35:144-50.

\section{Conflict of Interest}

The authors declare that they have no conflict of interest. 